\title{
Article
}

http://dx.doi.org/10.11646/phytotaxa.177.2.1

\section{Miscellaneous New Species of Brazilian Bromeliaceae - III}

\author{
ELTON M.C. LEME ${ }^{1}$, WALTER TILL², LUDOVIC J.C. KOLLMANN³, RICARDO L. DE MOURA ${ }^{4}$ \& OTÁVIO \\ B.C. RIBEIRO ${ }^{5}$ \\ ${ }^{1}$ Herbarium Bradeanum, C. Postal 15005, CEP 20031-970, Rio de Janeiro, RJ, Brazil.E-mail:_leme@tj.rj.gov.br \\ ${ }^{2}$ Herbarium of the Biodiversity Center, Faculty of Life Sciences, University of Vienna, Rennweg 14, A-1030 Wien, Austria. E-mail. \\ walter.till@univie.ac.at \\ ${ }^{3}$ Museu de Biologia Prof. Mello Leitão, Av. José Ruschi, 4, Santa Teresa, Espirito Santo, CEP 29.650-000, Brazil. E-mail: ludokoll@, \\ yahoo.com.br \\ ${ }^{4}$ Departamento de Botânica, Museu Nacional, Universidade Federal do Rio de Janeiro, Quinta da Boa Vista, São Cristóvão, Rio de \\ Janeiro, 20940-040, Rio de Janeiro, Brazil.E-mail: rmoura@acd.ufrj.br \\ ${ }^{5}$ Universidade Federal de Viçosa, Depto. Biologia Vegetal, 36570-000, Viçosa, MG, Brazil.E-mail: otavio@agroflor.com.br.
}

\begin{abstract}
The authors describe and illustrate 14 new Bromeliaceae species: Aechmea avaldoana, Ae. gregaria, Ae. timida, Alcantarea lanceopetala, A. nana, A. recurvifolia, Billbergia matogrossensis, Bromelia amplifolia, Cryptanthus walkerianus, Encholirium viridicentrum, Vriesea bifida, V. lilliputiana, V. magnibracteata and V. tubipetala.
\end{abstract}

Key words: Bromelioideae, morphology, Pitcairnioideae, taxonomy, Tillandsioideae

\section{Introduction}

The family Bromeliaceae, with 3,352 species and 58 genera (Luther 2012), is one of the most remarkable constituents of the tropical forests in the Americas and contributes significantly to the amazing biodiversity of the communities where they occur (Benzing 2000). Currently, 1,306 species are accepted to occur in Brazil belonging to 44 genera and 1,181 species and 23 genera recognized as endemic (Forzza et al. 2013). According to Sobral \& Stehmann (2009), from 1990 to 2006, 2,875 new angiosperm species were described in Brazil, including 280 new Bromeliaceae species. This rate of publication is considered a useful indicator of floristic richness as well as of lack of adequate floristic knowledge. This fact reveals huge gaps in our knowledge about the species that make up Brazilian biomes and highlights the need for improving scientific production by means of cooperative taxonomic networks and collaborative research as an essential strategy to surpass logistical difficulties, for example complex topography, resource scarcity, and reluctant policies.

The study presented here is the result of cooperative collecting efforts in underexplored sites in the highly biodiverse Atlantic forest biome, as well as in the Campos Rupestres and Cerrado domains in Espírito Santo, Minas Gerais, Mato Grosso, and Bahia, revealing new and thus far unknown species in Bromeliaceae.

\section{Material \& Methods}

The studied species were collected during field activities with the specific purpose of biodiversity discovery in Bromeliaceae. The descriptions and illustrations are based on careful examination of living, fertile material, including the use of a stereomicroscope, prior to voucher specimen preparation. Descriptive terminology follows Smith \& Downs (1974, 1977, 1979), with adaptations following Scharf \& Gouda (2008). Voucher specimens were pressed and dried following conventional methods and deposited in CEPEC, HB, R or RB (acronyms follow Index Herbariorum; Thiers continuously updated). Living specimens were grown at the Refúgio dos Gravatás, in Teresópolis, Rio de Janeiro following the guidelines recommended by the Convention on Biological Diversity (CBD 1993) for ex situ conservation. 
Observations:-This new species closely related to V. claudiana Leme, Trindade-Lima \& Ribeiro (2010c: 19), but can be distinguished from it by the purple-wine spotted leaf blades (vs. greenish-glaucous with darker green irregular cross-veins), primary bracts shorter to equaling the stipes ( $v s$. equaling to slightly exceeding the stipes), longer stipes $(2.5-3 \mathrm{~cm} v s .1-2 \mathrm{~cm})$, longer and narrower petals $(38 \times 11-12 \mathrm{~mm} v s .35 \times 13-14 \mathrm{~mm})$, bearing rounded basal appendages ( $v s$. acute, subobtuse to obtusely and irregularly bidentate), stamens shorter than the petals ( $v s$. exceeding the petals by a fraction of the anthers) and filaments not at all dilated toward the apex (vs. distinctly dilated). This new species can also be compared to V. marceloi Versieux \& Machado (2012: 37), differing from it by the larger

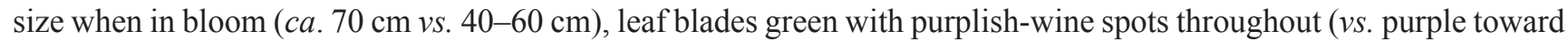
the apex and without spots), the usually longer peduncle $(35-37 \mathrm{~cm} v s .13 .5-25(-39) \mathrm{cm})$, peduncle bracts exceeding the internodes ( $v s$. shorter), stipes of the lateral branches longer $(2.5-3 \mathrm{~cm} v s .1 .1-2.1 \mathrm{~cm})$, longer flowers $(\mathrm{ca} .47 \mathrm{~mm}$ vs. 31-40 mm), longer petals (ca. $38 \mathrm{~mm} v s$. ca. $32 \mathrm{~mm}$ ) with obovate and rounded basal appendages (vs. lanceolate, acute to acuminate) and the stamens shorter to equaling the petals ( $v s$. distinctly exceeding).

\section{Acknowledgments}

We thank Eric Gouda, Gregory Brown and Jason Grant for their revision, valuable suggestions and advice during manuscript preparation; Instituto Estadual de Florestas (IEF) of Minas Gerais for providing the research permits and logistical support in the visited states parks; Avaldo Soares, José Carlos M. Falcon, Pedro Lima, Raymundo Reis. Jr. and Zildomar Magalhães, from Bahia, André P. Fontana and Marcos Zanoni, from Espírito Santo, Reginaldo Vasconcelos, from Minas Gerais, Walter Kranz, from Paraná and Bruno R. Silva and Rafael de Oliveira, from Rio de Janeiro, for their support and companionship during field activities and for providing some of the specimens and field information used in this study; and Peter Tristam, for reviewing the English text.

\section{References}

Benzing, D.H. (2000) Bromeliaceae: profile of an adaptive radiation. Cambridge University Press, Cambridge, pp.1-690.

Convention on Biological Diversity (1993) United Nations Environment Programme (UNEP). Available from: http://www.cbd.int/ convention/text/default.shtml.

Forzza, R.C., Costa, A., Siqueira-Filho, J.A., Martinelli, G., Monteiro, R.F., Santos-Silva, F., Saraiva, D.P., Paixão-Souza, B., Louzada, R.B. \& Versieux, L. (2013) Bromeliaceae. In: Lista de Espécies da Flora do Brasil. Jardim Botânico do Rio de Janeiro. Available from: http://floradobrasil.jbrj.gov.br/jabot/floradobrasil/FB66.

Forzza, R.C. \& Zappi, D. (2011) Side by side: two remarkable new species of Encholirium Mart. ex Schult. \& Schult. f. (Bromeliaceae) found in the Cadeia do Espinhaço, Minas Gerais, Brazil. Kew Bulletin 66: 281-287.

http://dx.doi.org/10.1007/s12225-011-9283-y

Grant, J.R. (1995) The resurrection of Alcantarea. Tropische und subtropische Pflanzenwelt 91: 7-15.

Gross, E. \& Rauh, W. (1987) Billbergia robert-readii, a striking new species from southern Peru. Journal of the Bromeliad Society 37 : $56-58$.

IUCN. Standards and petitions subcommittee. (2010) Guidelines for using the IUCN Red List Categories and Criteria. Version 8.0 Prepared by Standards and Petitions Subcommittee in March 2010. Available from: http://intranet.iucn.org/webfiles/doc/SSC/ RedList/RedListGuidelines.pdf

Lemaire, C.A. (1867) Vriesea glaziouana. L'Illustration Horticole 14 (misc.): 43-46.

Leme, E.M.C. (1997) Contribution to the study of the genus Alcantarea - II. Bromélia 4: 29-40.

Leme, E.M.C., Fontana, A.P. \& Ribeiro, O.B. de C. (2010a) Neues von Alcantarea: eine neue, große Art und "Pseudoviviparie" bei A. glaziouana. Die Bromelie 2010: 112-125.

Leme, E.M.C., Fraga, C.N., Kollmann, L.J.C., Brown, G.K., Till, W., Ribeiro, O.B.C., Machado, M.C., Monteiro, F.J.S. \& Fontana, A.P. (2010b) Miscellaneous new species in the Brazilian Bromeliaceae. Rodriguesia 61: 21-67.

Leme, E.M.C., Fraga, C.N., Kollmann, L.J.C \& Fontana, A.P. (2008) Three new Alcantarea species from Espírito Santo and Minas Gerais, Brazil. Journal of the Bromeliad Society 58: 205-216.

Leme, E.M.C. \& Kollmann, L.J.C. (2013) Miscellaneous new species of Brazilian Bromeliaceae. Phytotaxa 108: 1-40. http://dx.doi.org/10.11646/phytotaxa.108.1.1 
Leme, E.M.C. \& Siqueira-Filho, J.A. (2006) Taxonomia das bromélias dos fragmentos de mata atlântica de Pernambuco e Alagoas. In: Siqueira Filho, J.A. \& Leme, E.M.C. (Eds.) Fragmentos de Mata Atlântica do Nordeste, Biodiversidade, Conservação e suas Bromélias. Andrea Jakobsson Estúdio, Rio de Janeiro, pp.191-381.

Leme, E.M.C, Trindade-Lima, T. \& Ribeiro, O.B. de C. (2010c) Revision of the lithophytic Vriesea species from Minas Gerais State, Brazil - Part IV. Journal of the Bromeliad Society 60: 17-30.

Luther, H.E. (2012) An alphabetical list of bromeliad binomials. In: Holst, B.K. \& Rabinowitz, L. (Eds.) An alphabetical list of bromeliad binomials. Marie Selby Botanical Gardens, Sarasota \& Bromeliad Society International, 45 pp.

Mez, C. (1891) Bromeliaceae (part 1). In: Flora Brasiliensis 3(3). Martius, C.F.P. von, Eichler, A.W. \& Urban, I. (Eds.) F. Fleischer, Munich \& Leipzig, pp. 173-280.

Morren, E. (1880) Broméliacées nouvelles. La Belgique Horticole 30: 238-242.

Morren, E. (1882) Pl. CCCCLXVII Vriesea rodigasiana Ed. Morren, Vriesie rodigas, Broméliacées. L'Illustration Horticole 29: 171172.

Pereira, E. (1974) Species Novae in Brasilia Bromeliacearum - VII. Bradea 1: 437-446.

Scharf, U. \& Gouda, E.J. (2008) Bringing Bromeliaceae back to homeland botany. Journal of the Bromeliad Society 58: $123-129$.

Smith, L.B. (1941) Bromeliáceas novas ou interessantes do Brasil - I. Arquivos de Botânica do Estado de São Paulo 1: 53-60.

Smith, L.B. (1943) Bromeliáceas novas ou interessantes do Brasil-II. Arquivos de Botânica do Estado de São Paulo 1: $102-122$.

Smith, L.B. (1968) Notes on Bromeliaceae XXVII. Phytologia 16: 62-86.

Smith, L.B. \& Downs, R.J. (1974) Pitcairnioideae (Bromeliaceae). In: Flora Neotropica Monograph 14. Hafner Press, New York, pp. $1-662$.

Smith, L.B. \& Downs, R.J. (1977) Tillandsioideae (Bromeliaceae). In: Flora Neotropica Monograph 14. Hafner Press, New York, pp. $663-1492$.

Smith, L.B. \& Downs, R.J. (1979) Bromelioideae (Bromeliaceae). In: Flora Neotropica Monograph 14. The New York Botanical Garden, New York, pp. 1493-2142.

Sobral, M. \& Stehmann, J.R. (2009) An analysis of new angiosperm species discoveries in Brazil. Taxon 58: $227-232$.

Thiers, B. (continuously updated). Index Herbariorum: A global directory of public herbaria and associated staff. New York Botanical Garden's Virtual Herbarium. http://sweetgum.nybg.org/ih/ (accessed: 17 July 2014).

Versieux, L.M., Barbará, T., Wanderley, M.G.L., Calvente, A., Fay, M.F. \& Lexer, C. (2012a) Molecular phylogenetics of the Brazilian giant bromeliads (Alcantarea, Bromeliaceae): implications for morphological evolution and biogeography. Molecular Phylogenetics and Evolution 64: 177-189. http://dx.doi.org/10.1016/j.ympev.2012.03.015

Versieux, L.M., Vasconcelos, N., Martinelli, G. \& Wanderley, M.G.L. (2012b) Alcantarea pataxoana (Bromeliaceae), a new species from Bahia, Brazil. Systematic Botany 37: 636-640. http://dx.doi.org/10.1600/036364412x648580

Versieux, L.M. \& Machado, T.M. (2012) A new ornithophilous yellow-flowered Vriesea (Bromeliaceae) from Serra do Caraça, Minas Gerais, Brazil. Phytotaxa 71: 36-41.

Versieux, L.M. \& Wanderley, M.G.L. (2010) Delimitation of the Alcantarea extensa complex (Bromeliaceae) and a new species from Espírito Santo, Brazil. Rodriguesia 61: 421-429. 